\title{
An assessment of the contamination of Achatina achatina by toxic metals in Okpara village (Benin)
}

\author{
Patrick A. EDORH ${ }^{1 *}$, Eusèbe AGONKPAHOUN ${ }^{2}$, Kissao GNANDI ${ }^{3}$, Patient \\ GUEDENON $^{4}$, Luc KOUMOLOU ${ }^{5}$, Casimir AMOUSSOU ${ }^{4}$, Abel M. AYEDOUN ${ }^{6}$, \\ Michel BOKO ${ }^{4}$, Messanvi GBEASSOR ${ }^{5}$, Bertrand H. RIHN ${ }^{7}$ and Edmond E. CREPPY ${ }^{8}$ \\ ${ }^{1}$ Département de Biochimie et de Biologie Cellulaire, Université d'Abomey-Calavi (UAC), 01 BP 526 \\ Cotonou, Bénin. \\ ${ }^{2}$ UFR de Pharmacie, Faculté des Sciences de la Santé, Université d'Abomey-Calavi (UAC), 01 BP 526 \\ Cotonou, Bénin. \\ ${ }^{3}$ Laboratoire GTVD (Gestion, Traitement et Valorisation des Déchets), Université de Lomé, Faculté des \\ Sciences, BP 1515, Lomé, Togo. \\ ${ }^{4}$ Centre Interfacultaire de Formation et de Recherche en Environnement pour le Développement Durable \\ (CIFRED), Université d'Abomey-Calavi (UAC), 03 BP 1463, Jéricho, Cotonou, Bénin. \\ ${ }^{5}$ Département de Physiologie/Pharmacologie, Faculté des Sciences, Université de Lomé (UL), BP 1515 Lomé, \\ Togo. \\ ${ }^{6}$ Laboratoire de Médecine Biologique et Plantes Médecinales, Université de Parakou (UNIPAR), BP 123 \\ Parakou, Bénin. \\ ${ }^{7}$ Unité Inserm U525, Faculté de Pharmacie, 30 rue Lionnois, 54000 Nancy, France. \\ ${ }^{8}$ Laboratoire de Toxicologie et Hygiène Appliquée/UFR des Sciences Pharmaceutiques, 146, Rue Léo Saignat, \\ 33076 Bordeaux Cedex, France. \\ *Corresponding author, E-mail: patrickedorh@yahoo.fr, Tel: 00 (229) 97071596
}

\section{ABSTRACT}

The assessment of the contamination by toxic metals $(\mathrm{Pb}, \mathrm{Al}, \mathrm{Cd}, \mathrm{Cu}, \mathrm{Cr}, \mathrm{Zn}, \mathrm{Mn}$ ) has been achieved in samples of the giant snails (Achatina achatina) in the Okpara village (North of Benin). This work has been performed for, lately a survey revealed a strong contamination by toxic metals in sediments, water and fish in the Okpara River which waters this village. Otherwise, it is in this environment watered by the Okpara River, that snails are picked and consumed. The appropriated samples underwent the necessary treatment by mineralization before the analysis by electrochemical atomic absorption spectrophotometer (Varian A300 with Zeeman correction), in the Laboratory of Toxicology and Applied Hygiene/UFR of the Pharmaceutical Sciences (Bordeaux-France). The results of the analysis revealed a high bioaccumulation of heavy metals in all the samples and the concentrations exceed the recommended limits for human consumption. Only the level of chromium respects the recommended limits. This study permitted us to confirm as it has already proved by several authors, that the snail is a toxic metal bioaccumulator and can be considered therefore like a bioindicator of pollution, whose consumption will be a risk for health.
\end{abstract}

(c) 2009 International Formulae Group. All rights reserved.

Keywords: Environment pollution, snail quality, bioaccumulation, consumption risk.

\section{INTRODUCTION}

Nutrition problems in sub-Saharan Africa are characterized by a contribution in essentially constituted calories of cereals. The defaulting in proteins is very acute (Autret, 1992). However, there are unknown sources of proteins, although available and especially appreciated in some villages in developing 
countries (Hardouin, 1986). It is the case of the Okpara village, in the North of Benin, where the giant snail (Achatina achatina), is collected and consumed by the local population. Besides, the consumption of snails is part of the african gastronomy, even though the particularities are related to each region. However, these animals are part of the wild meats appreciated and their consumption remains the most elevated in Africa (Hardouin et al., 1995).

But a toxicological study was carried out earlier on the assessment of pollution by toxic metals in the Okpara River which waters this village. And the results indicated that waters, fishes and sediments of this aquatic ecosystem are contaminated. The levels of contamination are exceeded for lead, cadmium, aluminium, zinc and copper. The sources of this pollution would have a relation with the pollution of soils and other components of environment contaminated by the agricultural and other human activities (Agonkpahoun, 2007). Otherwise, the snail tiger, called also "giant Ghana tiger snail" or simply "Achatine" is usually polyphageous. Then, they consume soil, plants and breathe air (Upatham et al., 1988).

In this context, the study on the bioaccumulation of toxic metals by snails that are collected and gleefully consumed by the population of this village is necessary.

The main objective of this study is to once again draw attention on the threat posed by environmental pollution for the health quality of food resources (Gnandi et al., 2008).

\section{MATERIALS AND METHODS Study area}

Okpara is a northern village of Benin located about $12 \mathrm{~km}$ to the East of the town of Parakou. The climate of the region is tropical, with a dry season and a rainy season. Agriculture and especially the cotton culture are the main activities that characterize the entire region (Biaou et al., 2003).

The zone of collection of the snails is situated on the strand of the Okpara River that surrounds the village (Figure 1). This figure shows that Okpara River is a tributary of the Ouémé stream which communicates with the lagoon of Porto-Novo and Nokoué Lake in Cotonou, the most populated city of Benin (Le Barbe and Alé, 1993).

\section{Sampling}

The material is the achatina (Figure 2) collected in the Okpara village. Thirty-five sampling has been realized at random in November 2006, nearly at the end of the rainy season. The weight and the height of Achatina achatina are respectively about $12 \mathrm{~cm}$ and 225 g. Table 1 shows the frequency and the number of sampling for the appreciation of the representativity of sampling.

- For the variable height : Mode $=15$

- For the variable weight : Mode $=13$

The weight and the height of Achatina achatina are respectively about $12 \mathrm{~cm}$ and 225 g.

\section{Treatment and analysis}

The snails were collected and washed immediately with the river water to remove mud and algae. The samples were labelled and placed in air-tight plastic containers and packed in box with liquid nitrogen and transferred to the Laboratory of Toxicology and Applied Hygiene, University Victor Segalen Bordeaux 2, 146, Rue Léo Saignat, 33076 Bordeaux (France) for heavy metals analysis. The samples were weighted, measured and stored at $-20{ }^{\circ} \mathrm{C}$ until analysis. The flesh of the snails was mineralized and analysed by an electro-thermal atomic absorption spectrophotometer (Varian) attended by a quality control software according to Vaidya and Rantala (1996), Anane et al. (1997), and Mensi et al. (2008). Values of heavy metals were recorded in $\mathrm{mg} / \mathrm{kg}$.

Tests of significance were carried out using the statistical analysis software Stata 8.0. The "Proc means" procedure has been used to calculate the mean concentrations. The means have then been compared using the test $\mathrm{t}$ of Student $\mathrm{p}(\mathrm{T}>\mathrm{t})=0.05$. 


\section{RESULTS}

The results of the analysis of the samples are given in Table 2. We presented the maximal, minimal and median contents. The averages are given with standard deviation.

The highest mean concentrations obtained in the flesh of Achatina achatina are for copper $(439 \mathrm{mg} / \mathrm{kg})$ and zinc $(406.8$ $\mathrm{mg} / \mathrm{kg}$ ). The lowest mean concentrations in toxic metals are for chrome $(0.18 \mathrm{mg} / \mathrm{kg})$ and cadmium $(1.24 \mathrm{mg} / \mathrm{kg})$. For lead, aluminium and magnesium we obtained respectively in the flesh of Achatina achatina $8.56 \mathrm{mg} / \mathrm{kg}$, $52.34 \mathrm{mg} / \mathrm{kg}$ and $7.78 \mathrm{mg} / \mathrm{kg}$.

Table 3 compares our results with those of Agonkpahoun (2007) concerning fishes in the Okpara River. According to this Table 3, the averages in the same column are significantly different except for $\mathrm{Pb}$ and $\mathrm{Al}$ for which $\mathrm{p}>0.05$.

Table 4 shows the assessment of the consumer's exhibition according to $100 \mathrm{~g}$ daily consumption of snail.

The exposure is equal to the total quantity found in one sample for such metal multiplied by the quantity of snail consumed per day. For example, for lead, the Acceptable Daily Intake (ADI) is $3.6 \mu \mathrm{g} / \mathrm{kg}$ per Bodily Weight (BW) per day (CE, 2006).

\section{DISCUSSION}

\section{Toxic metals in the samples of the snails}

The different results show a level of contamination very alarming for some metals. These are lead, cadmium, copper and zinc. Aluminium and manganese are to be monitored. For the moment, there is no risk of toxicity for the chromium.

Otherwise, this work is the first assessment of the contamination of the giant snail in Benin. And particularly, the case of the contamination by lead is above all interesting, for it comes two years after the ban of leaded fuel in Benin (July 2005). The date of sampling is located at the end of heavy rains when there have been probably a resuspension of the soluble metal ions in water runoff into direct or indirect contact with the snails. This has certainly influenced the results which show that all the samples were heavily contaminated by toxic metals. In fact, the snail eats the soil, plants and breathes in the same environment. In these conditions, a redissolved metal ion in the water stream on the ground and on grass can promote the bioaccumulation of metals in the organs of the snail.

Achieved at the same period with the work of Agonkpahoun (2007) on the contamination by toxic metals in this Okpara River, our results should roughly reflect the same levels of contamination by toxic metals. But this is not the case. Table 3 compares our results with those of Agonkpahoun (2007) concerning fish species in the Okpara River. The relevance of this comparison is to show how two different species nearly living in the environments confronted to the same degree of pollution by the heavy metals can react. According to this Table 3, the averages in the same column are significantly different except for $\mathrm{Pb}$ and $\mathrm{Al}$ for which $\mathrm{p}>0.05$.

Although the snails and fishes don't live in the same biotope and that several parameters can influence the bioaccumulation differently with species, these differences which are too great must be explained. We could further explain that the snails would behave as passive bioaccumulative toxic metals. Then, they can be used as bioindicators of pollution by toxic metals. This assertion was already verified by the work of Gomot (1997).

For $\mathrm{Pb}$ and $\mathrm{Al}$, the statistical results show that it is only for these two metals that the standard deviations pass the mean concentration for the snails. In these conditions, because of technical reasons, these values would not be able to reflect the reality. However, these results can be explained otherwise. Leaded fuel has been banned in Benin for two years. It can be responsible for the lead reduction in this environment. Otherwise, Agonkpahoun (2007) had observed that the fishes of the Okpara River 


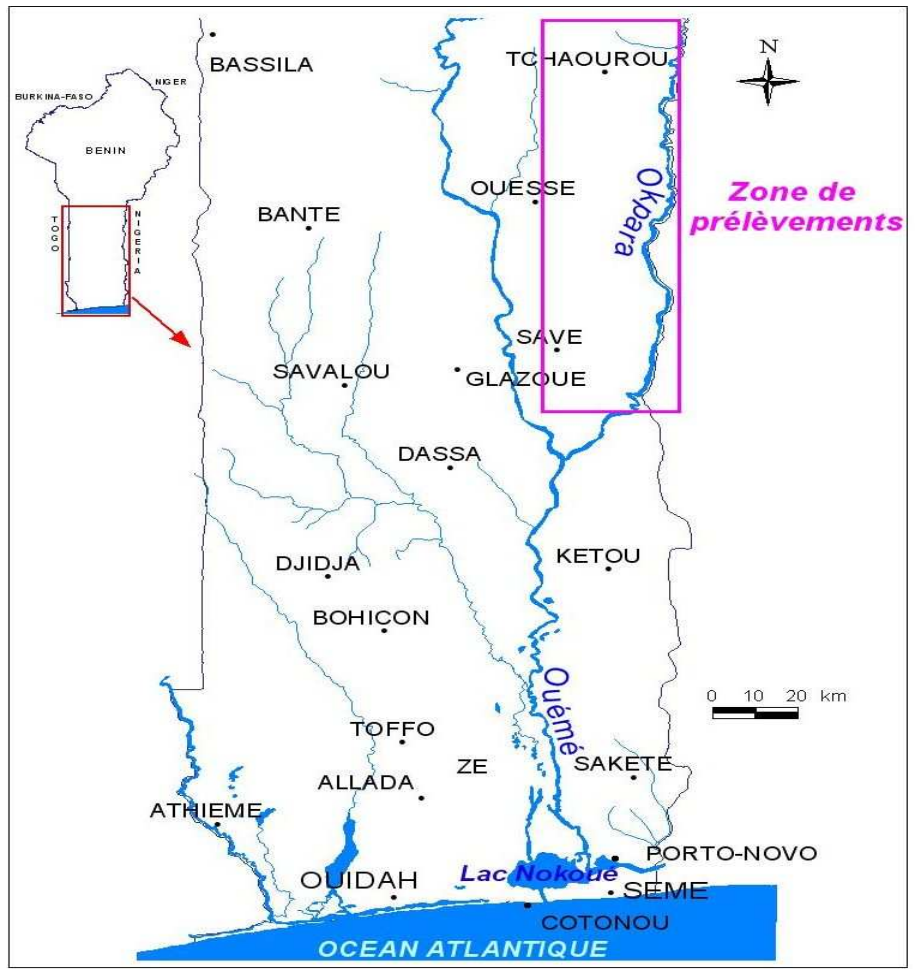

Figure1: Geographical situation of the Okpara River.

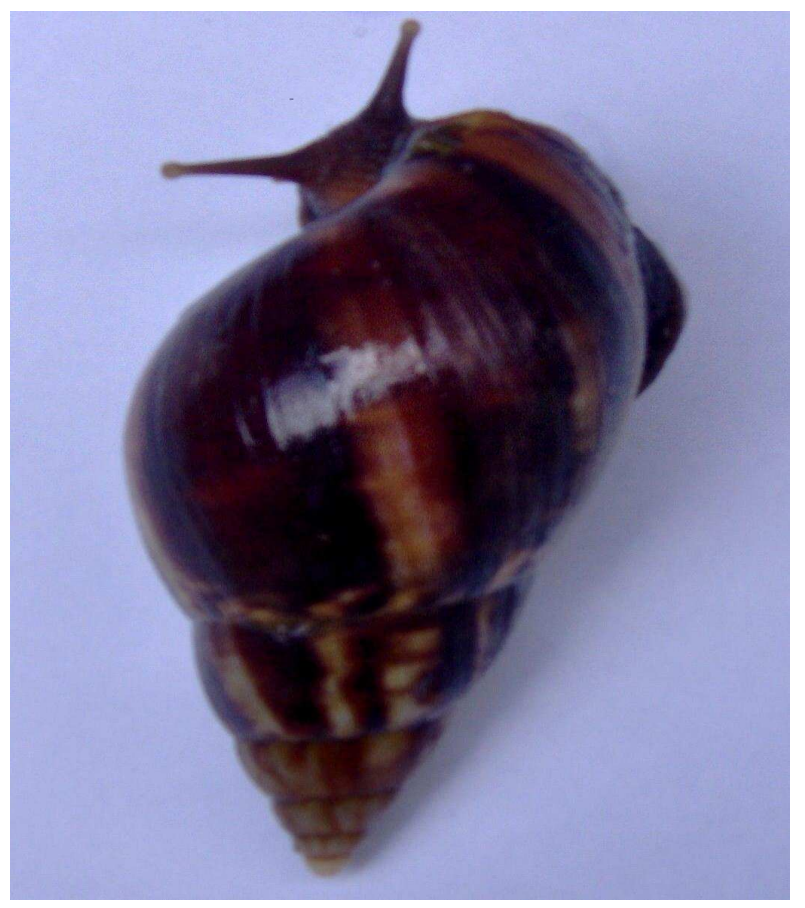

Figure 2: Photo of Achatina achatina. 
P. A. EDORH et al. / Int. J. Biol. Chem. Sci. 3(6): 1428-1436, 2009

Table 1: Frequency of the height and weight of samples.

\begin{tabular}{cccc}
\hline Height $(\mathrm{cm})$ & Frequency & Weight $(\mathrm{g})$ & Frequency \\
\hline $8-10$ & 1 & $125-150$ & 2 \\
$10-11$ & 3 & $150-175$ & 3 \\
$11-12$ & 10 & $175-200$ & 5 \\
$12-13$ & 15 & $200-225$ & 9 \\
$13-14$ & 5 & $225-250$ & 13 \\
$14-15$ & 1 & $250-275$ & 3 \\
\hline
\end{tabular}

Table 2: Toxic metals concentration of the samples.

\begin{tabular}{|c|c|c|c|c|c|c|c|}
\hline Metals (mg/kg) & $\mathbf{P b}$ & Al & Cd & $\mathbf{C u}$ & $\mathrm{Cr}$ & Zn & Mn \\
\hline$(\mathrm{WHO}, 2001)$ & 0.1 & 0.2 & 0.05 & 3 & 0.05 & 5 & 0.05 \\
\hline Sample of flesh $\mathrm{N}^{\circ} 1$ & 2.5 & 0.2 & 1.02 & 994 & 0.1 & 331 & 5.6 \\
\hline Sample of flesh $\mathrm{N}^{\circ} 2$ & 32.5 & 9 & 1.04 & 106 & 0.2 & 376 & 5 \\
\hline Sample of flesh $\mathrm{N}^{\circ} 3$ & 4 & 13 & 1.04 & 175 & 0.1 & 368 & 5 \\
\hline Sample of flesh $\mathrm{N}^{\circ} 4$ & 2.5 & 6.7 & 1 & 150 & 0.1 & 256 & 5.6 \\
\hline Sample of flesh $\mathrm{N}^{\circ} 5$ & 1.3 & 243 & 2.1 & 721 & 0.3 & 748 & 19.6 \\
\hline Sample of flesh $\mathrm{N}^{\circ} 6$ & 1.5 & 8 & 1.07 & 1084 & 0.1 & 361 & 8.6 \\
\hline Sample of flesh $\mathrm{N}^{\circ} 7$ & 42.5 & 9 & 0.04 & 109 & 0.3 & 356 & 5 \\
\hline Sample of flesh $\mathrm{N}^{\circ} 8$ & 3.5 & 7 & 1.12 & 180 & 0.2 & 307 & 9.6 \\
\hline Sample of flesh $\mathrm{N}^{\circ} 9$ & 1.5 & 6.9 & 1.7 & 143 & 0.03 & 229 & 4.9 \\
\hline Sample of flesh $\mathrm{N}^{\circ} 10$ & 1.9 & 117 & 2.2 & 622 & 0.3 & 756 & 17.4 \\
\hline Sample of flesh $\mathrm{N}^{\circ} 11$ & 2.6 & 12 & 1.06 & 997 & 0.4 & 329 & 5.7 \\
\hline Sample of flesh $\mathrm{N}^{\circ} 12$ & 29.4 & 7 & 1.5 & 123 & 0.2 & 345 & 5.3 \\
\hline Sample of flesh $\mathrm{N}^{\circ} 13$ & 4 & 8 & 1.4 & 145 & 0.1 & 268 & 4.5 \\
\hline
\end{tabular}


P. A. EDORH et al. / Int. J. Biol. Chem. Sci. 3(6): 1428-1436, 2009

\begin{tabular}{|c|c|c|c|c|c|c|c|}
\hline Sample of flesh $\mathrm{N}^{\circ} 14$ & 2.5 & 6.7 & 1 & 134 & 0.1 & 230 & 4.6 \\
\hline Sample of flesh $\mathrm{N}^{\circ} 15$ & 1.2 & 290 & 2.1 & 756 & 0.4 & 698 & 17.5 \\
\hline Sample of flesh $\mathrm{N}^{\circ} 16$ & 2.5 & 11 & 1.02 & 1044 & 0.1 & 287 & 6.6 \\
\hline Sample of flesh $\mathrm{N}^{\circ} 17$ & 33 & 7 & 1.04 & 106 & 0.2 & 380 & 3.5 \\
\hline Sample of flesh $\mathrm{N}^{\circ} 18$ & 4 & 8 & 1.04 & 186 & 0.1 & 363 & 4.5 \\
\hline Sample of flesh $\mathrm{N}^{\circ} 19$ & 2.4 & 7.5 & 1 & 134 & 0.1 & 256 & 5.6 \\
\hline Sample of flesh $\mathrm{N}^{\circ} 20$ & 1 & 285 & 2.1 & 715 & 0.4 & 789 & 20.1 \\
\hline Sample of flesh $\mathrm{N}^{\circ} 21$ & 2.5 & 11 & 1.02 & 1038 & 0.1 & 360 & 4.5 \\
\hline Sample of flesh $\mathrm{N}^{\circ} 22$ & 29 & 9 & 1.04 & 106 & 0.2 & 358 & 3.8 \\
\hline Sample of flesh $\mathrm{N}^{\circ} 23$ & 3.2 & 8 & 1.04 & 172 & 0.1 & 365 & 6.1 \\
\hline Sample of flesh $\mathrm{N}^{\circ} 24$ & 2.5 & 6.7 & 1.5 & 150 & 0.1 & 256 & 3.6 \\
\hline Sample of flesh $\mathrm{N}^{\circ} 25$ & 1.3 & 251 & 1.5 & 721 & 0.36 & 645 & 15 \\
\hline Sample of flesh $\mathrm{N}^{\circ} 26$ & 1.5 & 11 & 1.02 & 995 & 0.1 & 345 & 4.6 \\
\hline Sample of flesh $\mathrm{N}^{\circ} 27$ & 32.5 & 7 & 1.45 & 114 & 0.4 & 389 & 4.5 \\
\hline Sample of flesh $\mathrm{N}^{\circ} 28$ & 5 & 10.4 & 1.09 & 186 & 0.5 & 358 & 6.7 \\
\hline Sample of flesh $\mathrm{N}^{\circ} 29$ & 2 & 6.7 & 0.56 & 170 & 0.04 & 269 & 5.4 \\
\hline Sample of flesh $\mathrm{N}^{\circ} 30$ & 1.3 & 227 & 2.1 & 721 & 0.3 & 744 & 12.7 \\
\hline Sample of flesh $\mathrm{N}^{\circ} 31$ & 2.5 & 11 & 1.22 & 1121 & 0.1 & 310 & 6.5 \\
\hline Sample of flesh $\mathrm{N}^{\circ} 32$ & 30 & 11 & 1.04 & 134 & 0.1 & 375 & 4.5 \\
\hline Sample of flesh $\mathrm{N}^{\circ} 33$ & 4 & 9 & 1 & 183 & 0.05 & 390 & 3.7 \\
\hline Sample of flesh $\mathrm{N}^{\circ} 34$ & 2.5 & 6.7 & 0.25 & 224 & 0.1 & 237 & 9.8 \\
\hline Sample of flesh $N^{\circ} 35$ & 3.5 & 183 & 2 & 714 & 0.24 & 804 & 16.8 \\
\hline Maximale value & 42.5 & 290 & 2.2 & 1121 & 0.4 & 804 & 20.1 \\
\hline Médiane & 2.5 & 8 & 1.04 & 175 & 0.1 & 358 & 5.5 \\
\hline Minimale value & 1 & 0.2 & 0.04 & 106 & 0.04 & 229 & 3.5 \\
\hline Average & $8.56 \pm 12.76$ & $52.34 \pm 84.4$ & $1.24 \pm 0.52$ & $439.2 \pm 381.7$ & $0.18 \pm 0.1206$ & $406.8 \pm 187.1$ & $7.78 \pm 5.109$ \\
\hline
\end{tabular}

Tabulated values are mean \pm SD. The contents are given by comparison to the WHO norms for foods (WHO, 2001). 
Table 3: Comparison of the concentrations of heavy metals between snails and fishes in Okpara village.

\begin{tabular}{|c|c|c|c|c|c|c|c|}
\hline Metals $(\mathrm{mg} / \mathrm{kg})$ & $\mathbf{P b}$ & Al & Cd & $\mathbf{C u}$ & $\mathrm{Cr}$ & $\mathbf{Z n}$ & Mn \\
\hline Average for the samples of snails & $8.56 a$ & 52.34b & 1.24 & 439.20 & 0.18 & 406.80 & 7.78 \\
\hline $\begin{array}{l}\text { Average for samples of fishes } \\
\text { (Agonkpahoun, 2007) }\end{array}$ & $0.02 a$ & $7.50 \mathrm{~b}$ & 0.11 & 11.25 & 0.03 & 7.50 & 0.16 \\
\hline $\begin{array}{l}\text { Test } \mathrm{t} \text { : if } \mathrm{p}<0.05 \text { then Ho } \\
(\text { Ho: diff }=0 \text { ) accepted }\end{array}$ & 0.1922 & 0.3554 & 0.0002 & 0.0389 & 0.0176 & 0.0002 & 0.0068 \\
\hline
\end{tabular}

Values of the same column with the same letter are not significantly different $(\mathrm{p}>0.05)$

Table 4: Assessment of the consumer's exhibition according to $100 \mathrm{~g}$ daily consumption of snail.

\begin{tabular}{llc}
\hline $\begin{array}{l}\text { Metal } \\
(\mathbf{m g} / \mathbf{k g})\end{array}$ & $\begin{array}{l}\text { ADI } \\
(\boldsymbol{\mu g} / \mathbf{k g ~ B W} / \mathbf{D})\end{array}$ & $\begin{array}{c}\text { Consumers of 100 g/D of snails from the Okpara } \\
\text { village by an adult of } \mathbf{6 5} \mathbf{~ k g}\end{array}$ \\
\hline $\mathrm{Pb} 8.56$ & 3.6 & $856 \mu \mathrm{g}(8.56 \times 0.1 \mathrm{~kg})^{*}$ versus $234 \mu \mathrm{g}(3.6 \times 65 \mathrm{~kg})$ \\
$\mathrm{Al} 52.34$ & 2000 & $5.234 \mathrm{mg}$ versus $130 \mathrm{mg}$ \\
$\mathrm{Cd} 1.24$ & 1 & $124 \mu \mathrm{g}^{*}$ versus $65 \mu \mathrm{g}$ \\
$\mathrm{Cu} 439.2$ & 500 & $43.92 \mathrm{mg}$ versus $32.5 \mathrm{mg}$ \\
$\mathrm{Cr} 0.18$ & 15000 & $0.018 \mathrm{mg}$ versus $975 \mathrm{mg}$ \\
$\mathrm{Zn} 406,8$ & 300 & $40.68 \mathrm{mg}$ versus $19.5 \mathrm{mg}$ \\
$\mathrm{Mn} 7.78$ & 100 & $778 \mu \mathrm{g}$ versus $6500 \mu \mathrm{g}$ \\
\hline \multicolumn{2}{c}{ Dose/kg BW/D = Dose per kg of body weight/Day. } \\
* = Overtaking of the ADI for the $100 \mathrm{~g}$ daily ration of snail.
\end{tabular}

were not greatly contaminated by $\mathrm{Al}$, although the sediments of this river were strongly contaminated. $\mathrm{He}$ suggested that the bioavailability of $\mathrm{Al}$ was weak in this area, and this explains its relative few bioaccumulation also in the snails. Some reasons can explain this level of bioaccumulation of toxic metal in the snails. The Okpara village is one of the regions in Benin characterized by the intensive culture of the cotton (Ton and Wankpo, 2004) with the use of fungicides in the maintenance of the cultures (CICP, 2008) which are sources of contamination by the heavy metals (Deluisa and al., 1996). They would therefore influence the contamination of the soils, plants and others substrates which are in direct contact with Achatina achatina.

However, the snail would not be the only passively to bioaccumulate heavy metals and to be used as an indicator of pollution. In fact, most edible wild mushrooms are reservoirs of heavy metal without the latter have provided a significant effect on their biology (Michelot et al., 1998). Similar work also carried out on mussels showed that they are very good indicators of pollution because of their ability to bioaccumulate toxic metals. The worm (Ablain, 2002), lichens (Asta et al., 2002), foam (Empain, 1976), mussels (Bergman, 1993), carrot, cabbage (Garrec and van Haluwyn, 2002) are all good bioindicators of heavy metal pollution. These organisms, real reservoirs of toxic metals, constitute nevertheless a danger to their consumers, reason why it is important to assess the risk of toxicity faced by consumers of Achatina achatina in Okpara village.

\section{Assessment of consumer exposure and risk of intoxication}

The bioconcentration is a phenomenon that involves a food chain, the better, a food network. Thus, it goes back to consumers of higher level such as humans, more exposed than any other link in the chain. However, it is 
not uncommon to find Achatina eating human faeces, which increases the risk of exposure to the consumer of the snail.

This exposure will be calculated taking into account the mode of food and diet. To determine the amount absorbed and distributed in the body, one must take into account the bioavailability which varies greatly depending on the chemical forms of the metal in question. The exposure is equal to the total quantity found in one sample for such metal, multiplied by the quantity of snail consumed per day. For example, for lead, the Acceptable Daily Intake (ADI) is $3.6 \mu \mathrm{g} / \mathrm{kg}$ per Bodily Weight (BW) per day (CE, 2006). The average concentration of lead in the giant snail of the Okpara village is $8.56 \mathrm{mg} / \mathrm{kg}$ (Table 2). The consumption of only $100 \mathrm{~g}$ of flesh of a giant snail per day, which provide $17.7 \mathrm{~g}$ of proteins (Guèdègbé, 2004) will poison with $8.56 \mathrm{mg} \mathrm{X} 0.1$ of lead, either $0.856 \mathrm{mg}$. This value therefore largely exceeded the ADI. Only a person who ate $27 \mathrm{mg}$ of snail per day is protected from any exposure, at least in regard to the lead. The average weight of a giant snail exceeds $27 \mathrm{mg}$ (Kriss de Niort, 2008). The same calculation gives exposure situations that deserve to be taken seriously. These assessments are summarized in Table 3. Referring to this table, we can fear the worst for the people of the Okpara village, both for adults and children. However, exceeding ADI does not necessarily mean pathology, because food also contains substances capable of opposing the distribution of toxic metals in the body and its effects. These are antioxidants, polyphenols, sulphur and natural chelating metals. It also requires the elimination of certain metals with metabolic waste.

But all these results require more measures to be taken to preserve human health and biodiversity. Therefore, we must take measures to ensure the nutritional quality of snails, important sources of protein to develop in this century where food security is on the agenda. This will mainly reduce the risk of diseases to which consumers could be exposed.

\section{Conclusion}

Finally, this study is an assessment of the pollution by the toxic metals. It reveals that the environment of Benin, at least the Okpara village, is contaminated to such an extent that the contamination thresholds are exceeded for several metals.

We hope that works will be conducted to better understand the real causes of this pollution level in Okpara. For the moment, the assessment of human exposure showed that different concentrations in the flesh of snails could present an immediate or long term risk to the average consumers.

\section{REFERENCES}

Agonkpahoun ED. 2007. Evaluation de la pollution des eaux continentales par les métaux toxiques : cas de la riviere Okpara et du lac Nokoué au Bénin. Thèse de Pharmacie, $87 \mathrm{p}$.

Ablain F. 2002. Rôle des activités lombriciennes sur la redistribution des éléments traces métalliques issus de boue de station d'épuration dans un sol agricole. 148 p.

Anane R, Bonini M, Creppy EE. 1997. Transplacental passage of aluminum from pregnant mice to fetus organs after maternal transcutaneous exposure. Hum Exp Toxicol., 16(9): 501-504.

Asta J, Erhardt W, Ferretti M, Fornassier F, Kirschbaum U, Nimis PL, Purvis W, Pirintsos S, Scheidegger C, Van Haluwyn C, Wirth V. 2002. Mapping lichen diversity as an indicator of environmental quality. The Netherlands, 273-279.

Autret M. 1992. L'oeuvre de Corps de santé colonial dans le domaine alimentationnutrition Outre-Mer. Médecine et Nutrition, 28(5): 273-284.

Bergman A. 1993. Concentration of PAH, PCBs and heavy metals in the blue mussel Mytilus edulis. Project Polwad/Beon Effekt Ministry of Transport, Public Work and Water Managment of The Netherlands.

Blandin P. 1986. Bioindicateurs et diagnostic des systèmes écologiques. Bull. Ecol., 17(4): 215-306.

Biaou C, Alonso S, Truchot D, Abiola FA, Petit C. 2003. Contamination des cultures vivrières adjacentes et du sol lors d'une pulvérisation d'insecticides sur des 
champs de coton: cas du triazophos et de l'endosulfan dans le Borgou (Bénin).

CIPB, 2008. Etude monographique sur le coton.

CE (Communautés Européennes). 2006. Règlement (CE) No 1881/2006 : fixation de teneurs maximales pour certains contaminants dans les denrées alimentaires. Journal Officiel de l'Union Européenne, L 364 : 5-24.

Deluisa A, Giandon P, Aichner M, Bortolami P, Bruna L, Lupetti A, Nardelli F, Stringari G. 1996. Copper pollution in italian vineyard soils. Commun. Soil Sci. Plant Anal., 27: 1537-1548.

Empain A. 1976. Estimation de la pollution par les métaux lourds dans la Somme par l'analyse des bryophytes aquatiques. Bull. Fr. Piscicul., 260: 38-142.

Franciscans International. 2008. Rapport alternatif aux droits économiques, sociaux et culturels en république du Bénin. Nations Unies. 8p.

Garrec JP, Van Haluwyn C. 2002. Biosurveillance Végétale de la Qualité de l'Air. Ed. Tec. \& Doc. ; 117 p.

Gnandi K, Tozo K, Edorh AP, Abi H, Agbeko $\mathrm{K}$, Amouzouvi K, Baba G, Tchangbedji G, Killi K, Bouchet P, Akpagana K. 2008. Bioaccumulation de certains éléments métalliques dans les produits maraîchers cultivés sur les sols urbains le long de l'autoroute Lomé-Aného, Sud Togo. Acta Bot. Gallica, 155(3): 415-426.

Gomot A. 1997. Effets des métaux lourds sur le développement des escargots. Utilisation des escargots comme bio-indicateurs de pollution par les métaux lourds pour la préservation de la santé de l'homme. Bull. Acad. Natl. Med., 181(1): 59-74.

Guèdègbé R. 2004. Lexique de Biologie Humaine. Editions Syllabus.
Hardouin J. 1986. Mini-élevage et sources méconnues de protéines animales. Ann. Gx., 92: 153-162.

Hardouin J, Stiévenart C, Codjia JTC. 1995. L'achatiniculture : Elevage d'espèces non conventionnelles: une activité en plein essor. Agriculture and Consumer Protection, FAO.

INRA (Institut National de la Recherche Agronomique). 2004. Répertoire des essais d'utilisation de boues de stations d'épuration en milieu forestier. Publications de l'INRA, France.

Kriss de Niort. 2008. Escargot Tigre Achatine - Escargot Géant du Ghana Achatina achatina. Editions Faune.

Le Barbe L, Alé G. 1993. Les Ressources en Eaux Superficielles du Bénin. ORSTOM: Paris ; $540 \mathrm{p}$.

Mensi GS, Moukha S, Creppy EE, Maaroufi K. 2008. Metals Accumulation in Marine Bivalves and Seawater from theLagoon of Boughrara in Tunisia (North Africa). International Journal of Environmental Research, 2(3): 279-284.

Michelot D, Siobud-Dorocant E, Dore J-C, Viel C. 1998. Update on metal content profiles in mushrooms - pollution, toxicological profiles and tentative approach of the mechanisms of bioaccumulation. Toxicon, 36: 19972012.

Ton P, Wankpo E. 2004. La production du coton au Bénin. Agriterra, $N^{\circ}$ : AgriStudies 12.4.04 2795.

Upatham ES, Maleeya K, Viroon B. 1988. Cultivation of the geant African snail, Achatina fulica. Journal of Science Society of Thailand, 14: 24 - 40.

Vaidya CO, Rantala TTR. 1996. A comparative study of analitycal methods determination of heavy metal in mussels (Mytilis edulis) from eastern Canada. Int. Environ. Anal. Chemistry,63(3): 179-185. 